p-ISSN: 0125-961X

Scientific Article

\title{
PERKECAMBAHAN DAN PREDIKSI MASA HIDUP TIGA JENIS Dendrobium MENGGUNAKAN EMPAT MACAM FORMULASI MEDIA
}

\section{Seed germination and lifespan prediction of three Dendrobium spp. using four kinds of media formulations}

\author{
Elizabeth Handini ${ }^{*}$, Dwi Murti Puspitaningtyas
}

Pusat Penelitian Konservasi Tumbuhan dan Kebun Raya - LIPI

Jl. Ir. H. Juanda No. 13 Bogor 16003

\section{Informasi Artikel}

\section{Diterima/Received : 3 Juli 2020}

Disetujui/Accepted : 26 November 2020

Diterbitkan/Published : 1 Desember 2020

*Koresponden E-mail :

lizahandini@gmail.com

\section{DOI: $\underline{\text { https://doi.org/10.14203/bkr.v23i3.647 }}$}

\section{Cara mengutip}

Handini E, Puspitaningtyas DM. 2020.

Perkecambahan dan prediksi masa hidup tiga jenis Dendrobium serta menggunakan empat macam formulasi media. Buletin Kebun Raya 23(3): 187-195. DOI:

https://doi.org/10.14203/bkr.v23i3.647

\section{Kontributor}

Kontributor Utama/Main author:

Elizabeth Handini

Dwi Murti Puspitaningtyas

Kontributor Anggota/Author member:

Keywords: Dendrobium, in vitro, germination test, seed storage

Kata Kunci: Dendrobium, in vitro, penyimpanan biji, uji daya kecambah

\begin{abstract}
Dendrobium is an important genus in Orchidaceae because it is widely used in crossbreeding and cut flowers. Seed is a valuable material for propagation as well as useful for maintaining genetic diversity. Seed banks play an important role in orchid conservation. This study aimed to find out the viability of Dendrobium macrophyllum, D. discolor, and D. crumenatum seeds, after being stored for 10 years, predicting the lifespan of seed, and knowing the appropriate germination medium. The method of testing seed viability is directly by germinating the seeds orchids on 4 culture media and calculate the percentage of seed germination. Seeds are stored at $-20^{\circ} \mathrm{C}$. Seed viability test was carried out in media: that are modified of Knudson'C (KC), Vacin and Went (VWs), Hyponex (HS) and Knudson C + micro elements (KCA). The results show that $D$. discolor seeds can be stored for up to 60 years, $D$. macrophyllum seeds can last up to 20 years, while $D$. crumenatum seeds lose viability after 9 years of storage. After nine years, the highest percentage of germination achieved by $D$. discolor was around $52.17 \%$. The best medium for $D$. macrophyllum and $D$. crumenatum seed germination was KC. While $D$. discolor seeds germinated well on HS media.
\end{abstract}

\begin{abstract}
Abstrak
Dendrobium merupakan marga penting dalam suku Orchidaceae karena banyak digunakan dalam persilangan dan bunga potong. Biji merupakan bahan penting untuk perbanyakan sekaligus berguna untuk memelihara keanekaragaman genetik. Bank biji memainkan peranan penting dalam konservasi anggrek. Penelitian ini bertujuan untuk mengetahui viabilitas biji anggrek Dendrobium macrophyllum, $D$. discolor, dan $D$. crumenatum setelah disimpan selama 10 tahun, memprediksi umur simpan biji, dan mengetahui media perkecambahan yang tepat. Metode pengujian viabilitas biji adalah dengan secara langsung dengan mengecambahkan biji anggrek pada 4 media kultur dan menghitung persentase perkecambahan biji. Biji disimpan pada suhu $-20^{\circ} \mathrm{C}$. Media uji: modifikasi Knudson'C (KC), Vacin dan Went Semai (VWS), Hyponex Semai (HS) dan Knudson C ditambah unsur mikro (KCA). Berdasarkan perkiraan masa hidup $D$. discolor dapat disimpan hingga lebih dari 60 tahun. D. macrophyllum diperkirakan mencapai 20 tahun, sedangkan $D$. crumenatum kehilangan viabilitasnya setelah disimpan selama 9 tahun. Dalam periode simpan 9 tahun, tingkat persentase perkecambahan biji $D$. discolor adalah yang tertinggi sekitar $52,17 \%$ di antara ketiga species anggrek tersebut. Media KC adalah media yang menghasilkan persentase perkecambahan tertinggi untuk $D$. macrophyllum dan $D$. crumenatum, sedangkan biji $D$. discolor berkecambah baik pada media HS.
\end{abstract}

bunga bervariasi, tangkai bunga lentur dan produktivitas bunga tinggi. Dari 20 seksi Dendrobium, dua seksi yang banyak digunakan sebagai induk silangan yaitu Ceratobium dan Phalaenanthe. Kedua seksi tersebut berkontribusi sebagai bunga potong dan tanaman hias dalam pot. $D$. discolor Lindl. termasuk dalam seksi Ceratobium, dan D. macrophyllum A. Rich. termasuk dalam seksi Latourea telah digunakan sebagai tetua dalam persilangan anggrek (Widiastoety et al. 2010). Selain sebagai tanaman hias, ada beberapa jenis yang 
memiliki potensi besar sebagai agensia anti mikroba, salah satu di antaranya adalah $D$. crumenatum Sw. yang mengandung senyawa alkaloid flavonoid tertentu (Sandrasagaran et al. 2014).

Strategi konservasi ex situ yang efektif untuk menyimpan material tanaman hidup dalam jumlah besar pada satu tempat adalah Bank Biji (Anonim 1997; Linington \& Pritchard 2001). Saat ini bank biji anggrek telah memberikan kontribusi yang signifikan dalam konservasi anggrek (Seaton \& Pritchard 2011). Meskipun perbanyakan dengan biji lebih banyak menghadapi tantangan, baik dari segi teknologi maupun budidayanya, namun biji mempunyai peran sangat penting sebagai bahan perbanyakan untuk mempertahankan keragaman genetiknya. Selain itu, untuk tujuan konservasi jangka panjang, biji dapat disimpan dalam ruang yang sempit dan dalam waktu yang relatif lama.

Jumlah biji yang dihasilkan oleh suatu jenis anggrek sangat besar mulai dari 376 biji hingga empat juta biji per buah, sedangkan per tanaman dapat mencapai 74 juta biji. Berat biji anggrek berkisar antara 0,31 $\mu$ g hingga 24 $\mu \mathrm{g}$ dengan ukuran yang bervariasi, dengan panjang $0,05-$ $6,00 \mathrm{~mm}$. Biji memiliki ruang udara bebas di dalam testa sekitar 16\%-90\% dari total volumenya. Biji anggrek kadang-kadang tanpa embrio (kosong) atau memiliki viabilitas yang rendah. Dengan demikian, sebelum melakukan konservasi biji anggrek, sangat penting untuk melakukan uji fisiologis terlebih dahulu. Uji perkecambahan biji secara langsung merupakan metode yang paling sering digunakan untuk menentukan kualitas biji dalam memproduksi tanaman (Hosomi et al. 2011).

Biji anggrek dinyatakan berkecambah apabila terjadi pembentukan protokorm yaitu struktur tertentu yang terbentuk saat biji berkecambah, berbentuk bulat dan belum mempunyai daun, batang, dan akar. Dua metode yang sering digunakan untuk menghitung keberhasilan perkecambahan biji adalah pengujian viabilitas biji langsung dan tidak langsung. Metode pengujian viabilitas biji secara langsung meliputi penghitungan perkecambahan benih anggrek pada media buatan dengan menghitung jumlah benih yang berkecambah atau belum berkecambah (Singh 1981; van Waes \& Debergh 1986). Metode pengujian viabilitas biji tidak langsung dilakukan dengan memeriksa aktivitas metabolisme biji dengan bantuan bahan pewarna kimia, seperti garam tetrazolium atau Flourescein diacetate (Pritchard 1985; Merritt et al. 2014). Penelitian ini menggunakan metode pengujian viabilitas biji langsung dengan menghitung jumlah biji-biji yang berkecambah maupun tidak berkecambah secara langsung (Puspitaningtyas \& Handini 2014).
Perkecambahan biji anggrek secara in vitro memiliki banyak keuntungan, antara lain: menghasilkan bibit sehat dalam jumlah banyak dan lebih cepat dibandingkan dengan yang terjadi di alam. Metode ini ideal untuk digunakan dalam produksi anggrek secara komersial dan regenerasi biji secara cepat. Hal ini juga berpotensi besar sebagai metode perbanyakan anggrek yang langka atau terancam kepunahan (Nadarajan et al. 2011). Penelitian ini menggunakan teknik perkecambahan secara in vitro untuk menguji daya tumbuh biji anggrek yang sudah disimpan. Penelitian ini bertujuan untuk mengetahui daya kecambah biji 3 jenis anggrek Dendrobium setelah disimpan selama 10 tahun, memprediksi daya simpannya, dan mengetahui media perkecambahan yang tepat.

\section{BAHAN DAN METODE}

\section{Proses penyimpanan biji}

Penelitian dilakukan di Laboratorium Kultur Jaringan, Pusat Penelitian Konservasi Tumbuhan dan Kebun Raya-LIPI Bogor, mulai 2008 hingga 2019. Dalam penelitian ini menggunakan 3 jenis anggrek, yaitu Dendrobium macrophyllum, $D$. discolor, dan $D$. crumenatum yang merupakan koleksi Kebun Raya Bogor. Biji-biji ketiga jenis anggrek tersebut dikeluarkan dari buah yang telah masak sempurna dengan menggunakan spatula dan dipisahkan dari serabut-serabut buah. Biji ditampung pada cawan petri dan disimpan dalam desikator selama 5 hari untuk mengurangi kadar air. Selanjutnya, biji dimasukkan dalam botol kecil kedap udara, dimasukkan kedalam botol besar, diberi satu bungkus silica gel sebagai indikator kelembapan, dan diberi label nama serta tanggal penyimpanan. Penyimpanan dilakukan dalam freezer $-20^{\circ} \mathrm{C}$.

Biji anggrek bersifat ortodok, sehingga perlu pengeringan untuk memperpanjang masa simpan. Pengeringan dilakukan hingga kadar air 5\% (Seaton et al. 2013). Biji anggrek yang disimpan di bawah kelembapan dan suhu rendah secara ex situ dapat bertahan selama beberapa dekade dan tahan terhadap bahan sterilan hipoklorit yang digunakan untuk sterilisasi dalam perkecambahan in vitro (Whigham et al. 2006). Teknik penyimpanan ini telah rutin dipakai untuk penyimpanan biji berbagai jenis anggrek (Seaton et al. 2010).

\section{Uji perkecambahan biji}

Uji perkecambahan biji dimulai dengan melakukan sterilisasi biji sebelum disemai. Sampel biji sebanyak 0,3 g diambil dan dimasukkan ke dalam aquades steril yang telah diberi tiga tetes Tween, divakum selama satu jam, 
dan proses selanjutnya dilakukan dalam laminar air flow. Larutan Tween dibuang dengan pipet setelah biji tenggelam, kemudian biji direndam dalam larutan Clorox $10 \%$ selama 10 menit, dan larutan Clorox $5 \%$ selama 5 menit. Biji dibilas dengan aquades steril tiga kali. Pada bilasan ketiga, aquades steril digunakan untuk mendistribusikan biji ke media-media semai dalam cawan petri. Setelah diratakan, aquades steril tersebut dihisap dan dikeluarkan, sehingga hanya biji yang tersisa di atas media semai. Cawan petri ditutup dan diberi label tentang informasi jenis, media dan tanggal tanam kemudian diperkuat dengan plastic wrap. (Puspitaningtyas \& Handini 2014).

Media semai biji yang digunakan ada empat macam, yaitu: KCA (Knudson $\mathrm{C}$ murni dengan penambahan unsur mikro antara lain $\mathrm{H}_{3} \mathrm{BO}_{3}$ sebanyak 0,056 $\mathrm{mg} \mathrm{L}^{-1}, \mathrm{MoO}_{3}$ 0,016 $\mathrm{mg} \mathrm{L}^{-1}$, ZnSO 4 0,331 $\mathrm{mg} \mathrm{L}^{-1}$, dan $\mathrm{CuSO}_{4} \quad 0,624 \mathrm{mg} \mathrm{L}^{-1}$ (Seaton \& Ramsay 2005), KC (modifikasi Knudson $\mathrm{C}$ dengan penambahan arang aktif sebanyak $1 \mathrm{~g} \mathrm{~L}^{-1}$, ekstrak taoge $150 \mathrm{~g} \mathrm{~L}^{-1}$ dan air kelapa 150 $\mathrm{ml} \mathrm{L}^{-1}$ ), VWs (modifikasi Vacin dan Went dengan penambahan arang aktif sebanyak $1 \mathrm{~g} \mathrm{~L}^{-1}$, ekstrak taoge $100 \mathrm{~g} \mathrm{~L}^{-1}$, tomat $100 \mathrm{~g} \mathrm{~L}^{-1}$ dan air kelapa $150 \mathrm{ml} \mathrm{L}^{-1}$ ), dan $\mathrm{HS}$ (pupuk daun Hyponex 25:5:20 dengan penambahan arang aktif sebanyak $1 \mathrm{~g} \mathrm{~L}^{-1}$, pepton $2 \mathrm{~g} \mathrm{~L}^{-1}$ dan kentang $40 \mathrm{~g} \mathrm{~L}^{-1}$ ) (Puspitaningtyas \& Handini 2014). Formulasi media ini dibuat dengan penambahan gula sebanyak $20 \mathrm{~g} \mathrm{~L}^{-1}$, agar pemadat $7 \mathrm{~g} \mathrm{~L} \mathrm{~L}^{-1}$, dan $\mathrm{pH}$ diatur $5.7-5.8$ sebelum penambahan agar, dan diotoklaf selama 20 menit dengan tekanan 15 psi. Medium dibagikan pada cawan petri steril di dalam laminar air flow sebanyak $15 \mathrm{ml}$ tiap cawan. Setelah penyemaian biji anggrek pada cawan medium, kemudian disimpan di dalam ruang kultur dengan suhu $25 \pm 2^{\circ} \mathrm{C}$ dan fotoperiodisitas 12 jam/hari serta menggunakan intensitas cahaya 40 Watt.

Perkecambahan biji diamati pada 30 hari setelah penyemaian. Untuk tiap jenis anggrek yang diuji, penyemaian dilakukan sebanyak 3 petri untuk setiap medium uji. Uji perkecambahan ketiga jenis anggrek Dendrobium pada empat medium di atas dilakukan secara periodik, yaitu sekali dalam setahun pada bulan Oktober.

\section{Analisis data}

Biji yang mulai berkecambah diamati dan dihitung di bawah mikroskop dengan perbesaran 40x. Perkecambahan biji anggrek ditunjukkan saat embrio telah muncul dari testa (Whigham et al. 2006). Persentase perkecambahan diperoleh dari jumlah biji yang berkecambah pada setiap 100-200 biji yang disemai dalam satu cawan petri dan dihitung dengan persamaan sebagai berikut:

Persentase perkecambahan (\%)

$=\frac{\text { jumlah biji berkecambah }}{\text { total jumlah biji yang diamati }} \times 100 \%$

(Hossain \& Dey 2013)

Masing-masing perlakuan media diulang sebanyak tiga ulangan (Puspitaningtyas \& Handini 2014).

Prediksi masa hidup biji dihitung dengan forecast sheet dari excel pada aplikasi Microsoft 365 yangditunjukkan dengan grafik garis tertinggi dan terendah. Prediksi dilakukan pada semua data persentase kecambah masing-masing media semai hingga periode lama simpan biji dapat mencapai titik 0\%. Pengaruh media semai terhadap perkecambahan biji dianalisis menggunakan sidik ragam SAS versi 9.00 dan nilai rerata dibandingkan untuk menunjukkan beda nyata dengan menggunakan uji Duncan dengan tingkat signifikansi 5\%.

\section{HASIL DAN PEMBAHASAN}

\section{Uji viabilitas dan prediksi masa hidup}

Biji D. macrophyllum, D. discolor, dan D. crumenatum memiliki karakter seperti biji anggrek pada umumnya, yaitu berukuran sangat kecil seperti debu, fusiform, tidak mempunyai endosperma, dan memiliki embrio yang tidak berdiferensiasi yang tertutup dalam mantel biji yang transparan. Perkecambahan biji anggrek di alam tergantung pada mikoriza. Namun kebutuhan akan keberadaan mikoriza dapat digantikan dengan pasokan gula dan nutrisi mineral lainnya secara in vitro, dan beberapa jenis anggrek dengan beragam kebiasaan dan habitatnya telah berhasil merespon perkecambahan asimbiotik (Gupta 2016).

Hasil pengujian perkecambahan biji tiga jenis anggrek secara in vitro menggunakan empat media semai (KCA, KC, VWs, dan HS), mulai 0 sampai 10 tahun, serta prediksi masa hidup biji masing-masing jenis anggrek tersebut ditampilkan pada Gambar 1-3. Gambar tersebut menunjukkan kemampuan media semai yang beragam dalam mendukung perkecambahan ketiga jenis anggrek tersebut. 

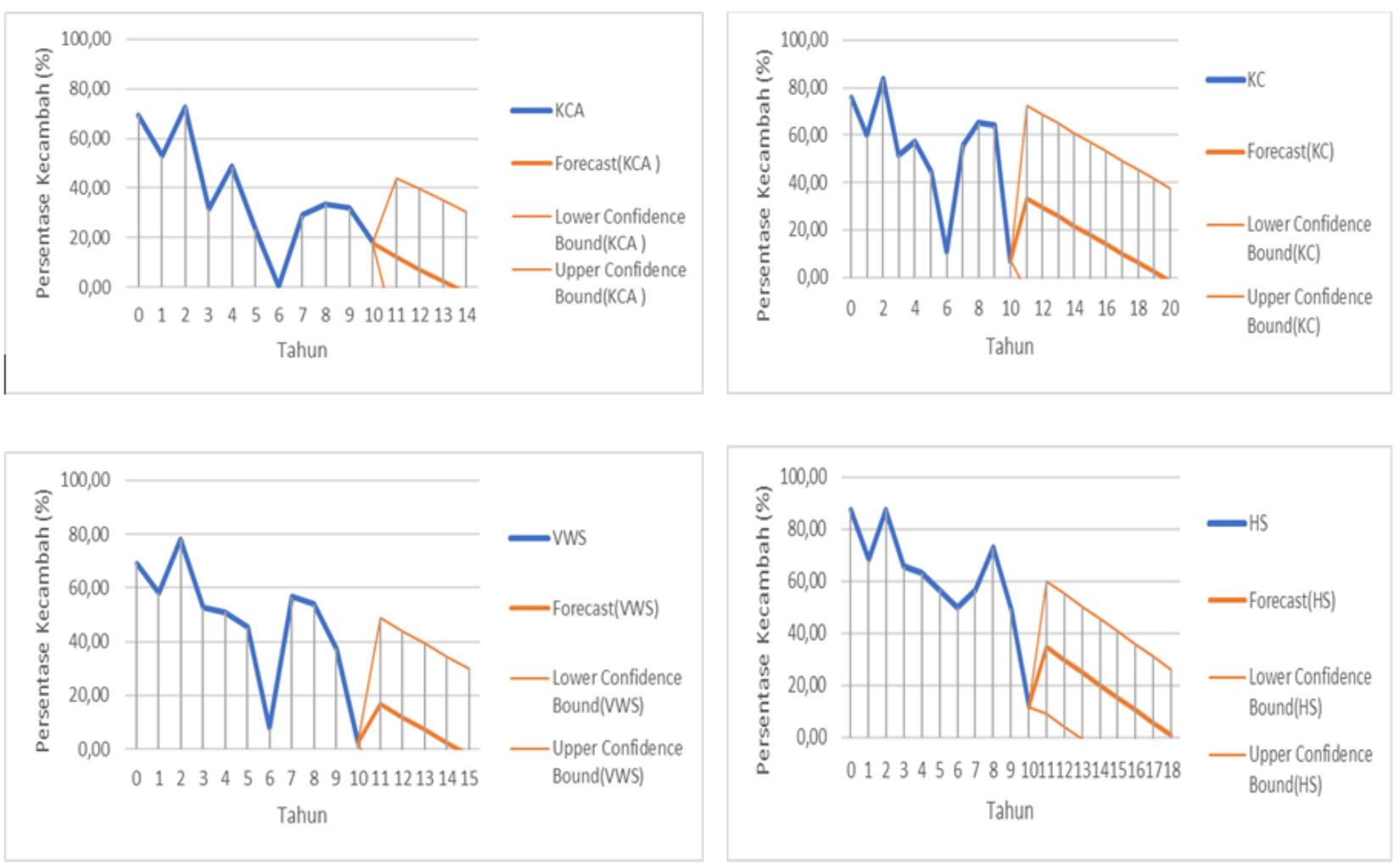

Gambar 1. Prediksi masa hidup biji D. macrophyllum hingga mencapai 0\%. Perkecambahan biji di media KCA (sekitar 13 tahun), KC (20 tahun), VWS (15 tahun), dan HS (18 tahun)


Gambar 2. Prediksi masa hidup biji $D$. discolor hingga mencapai 0\%. Perkecambahan biji di media KCA (sekitar 30 tahun), KC (26 tahun), VWS (16 tahun), dan HS (lebih dari 60 tahun)

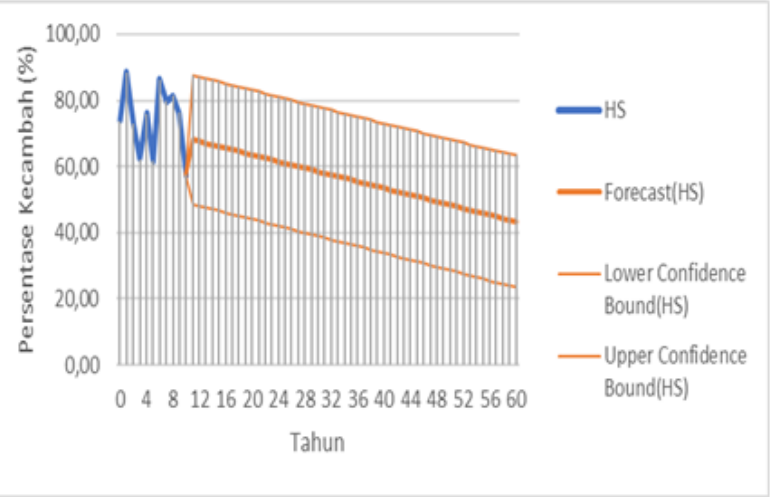



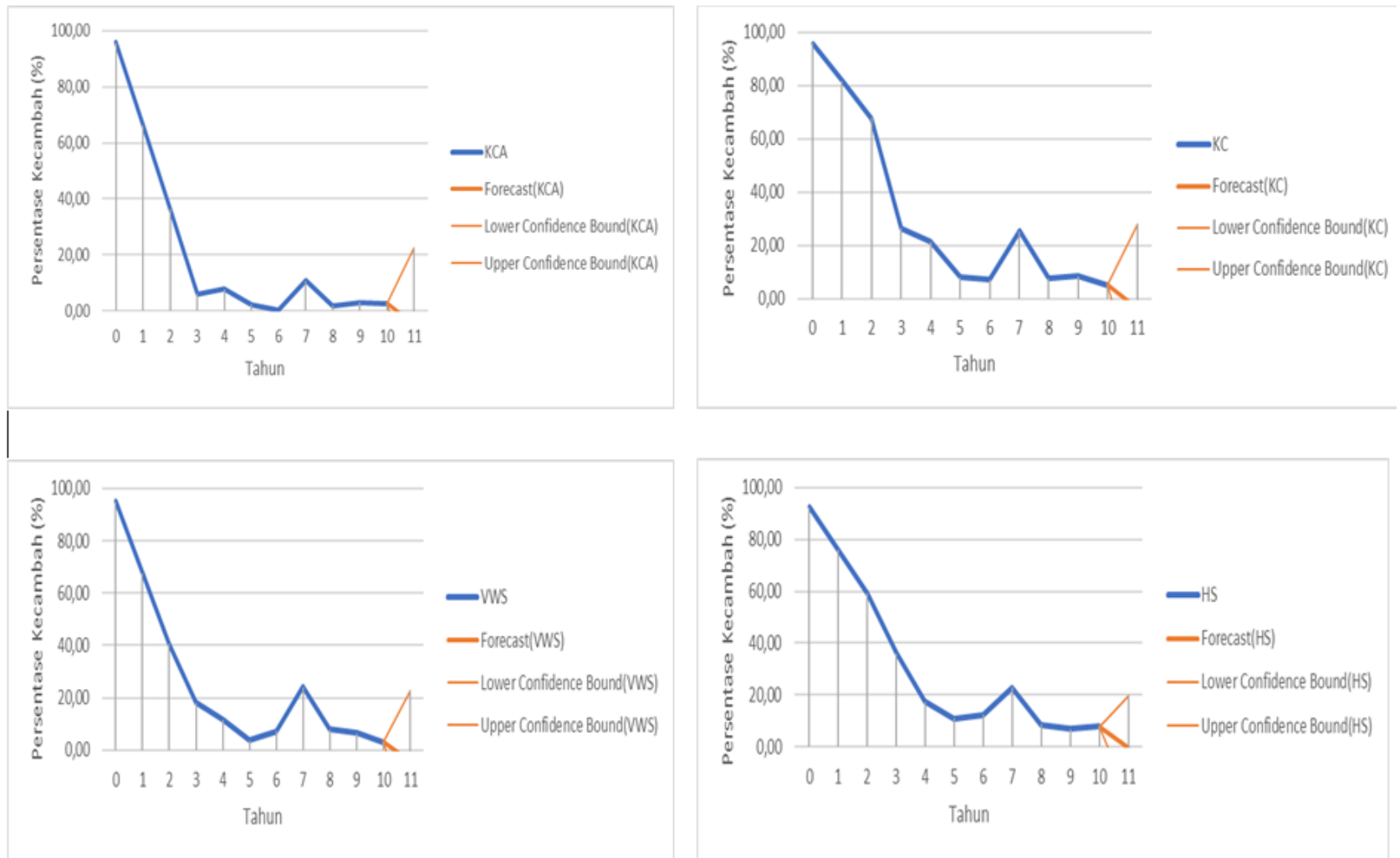

Gambar 3. Prediksi masa hidup biji D. crumenatum hingga mencapai $0 \%$. Perkecambahan biji di media KCA (sekitar 30 tahun), KC (26 tahun), VWS (16 tahun), dan HS (lebih dari 60 tahun).

Media yang paling mendukung perkecambahan biji D. macrophyllum adalah media KC dengan prediksi masa simpan hingga 20 tahun berdasarkan forecast sheet (Gambar 1). Hasil penelitian ini mendukung Rahayu \& Mulyani (2020) yang menyebutkan bahwa media KC merupakan media semai yang paling baik untuk perkecambahan anggrek $D$. spectabile.

Media paling baik untuk prekecambahan $D$. discolor adalah HS dengan masa simpan lebih dari 60 tahun berdasarkan forecast sheet (Gambar 2). Pada $D$. crumenatum, dari empat media semai yang dicoba untuk perkecambahan semuanya memperlihatkan respon yang hampir seragam yaitu mendekati $0 \%$ pada masa simpan 10 tahun (Gambar 3). Dengan demikian, biji $D$. crumenatum dapat berkecambah dengan baik pada keempat media tersebut.

\section{Respon kecambah biji anggrek}

Kemampuan hidup biji tiga jenis anggrek dapat dilihat secara lebih detil dari hasil analisis sidik ragam yang diambil dari data sembilan tahun masa simpan (Tabel 1). . Hal ini dikarenakan data pada 10 tahun masa simpan $D$. crumenatum sudah kehilangan daya kecambahnya, sehingga tidak dapat dibandingkan dengan jenis yang lain. Kecepatan perkembangan kecambah biji anggrek selanjutnya sangat dipengaruhi oleh nutrisi yang terkandung dari media semai.

Tabel 1. Uji daya kecambah pada penyimpanan 9 tahun

\begin{tabular}{lccc}
\hline Media & \multicolumn{3}{c}{ \% perkecambahan biji } \\
\cline { 2 - 4 } & D. macrophyllum & D. discolor & D. crumenatum \\
\hline KCA & $31,79 \mathrm{c}$ & $42,48 \mathrm{c}$ & $2,97 \mathrm{~b}$ \\
KC & $64,05 \mathrm{a}$ & $63,88 \mathrm{~b}$ & $8,57 \mathrm{a}$ \\
VWs & $37,51 \mathrm{bc}$ & $26,03 \mathrm{~d}$ & $6,49 \mathrm{ab}$ \\
HS & $49,57 \mathrm{ab}$ & $76,28 \mathrm{a}$ & $7,00 \mathrm{a}$ \\
\hline Rerata & 45,73 & 52,17 & 6,26 \\
\hline
\end{tabular}

Keterangan: angka dalam satu kolom yang diikuti notasi huruf yang sama tidak berbeda nyata pada tingkat signifikasi $P=5 \%$

Mulai munculnya akar rambut (rhizoid) pada ketiga jenis anggrek pada masing-masing media semai sangat beragam. Hal ini ditentukan oleh kesesuaian media semai dalam mendukung perkecambahan biji anggrek. Akar rambut muncul paling awal pada media KC pada D. macrophyllum (Gambar 4), D. discolor (Gambar 5), dan D. crumenatum (Gambar 6). 

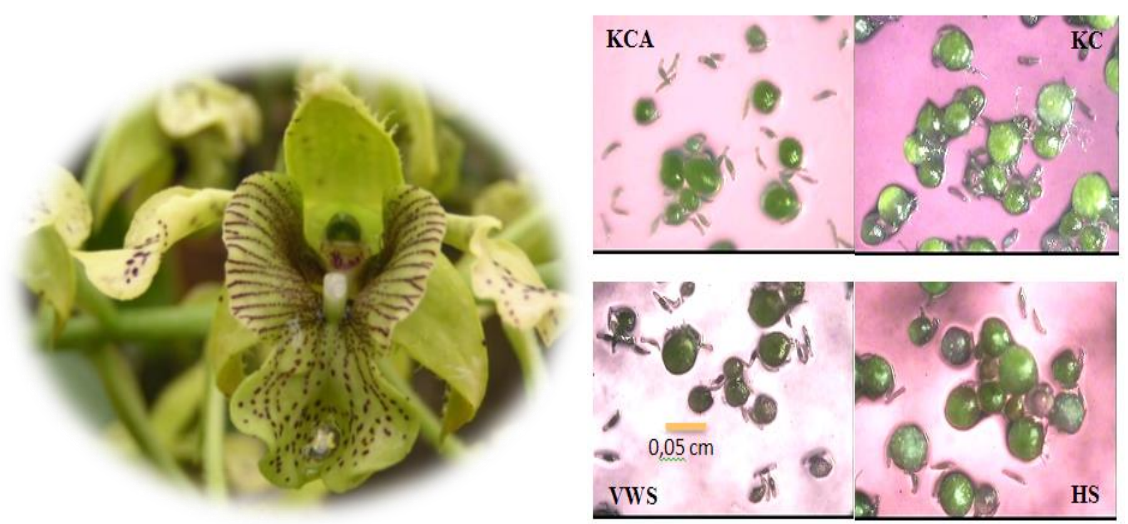

Gambar 4. Morfologi bunga dan pertumbuhan kecambah $D$. macrophyllum pada keempat media semai dari data biji simpanan 9 tahun. Kecambah $D$. macrophyllum yang tumbuh di media semai KC lebih tinggi persentasenya dan lebih cepat pertumbuhannya yang ditandai dengan adanya akar rambut (rhizoid). Foto bunga: Koleksi D.M. Puspitaningtyas

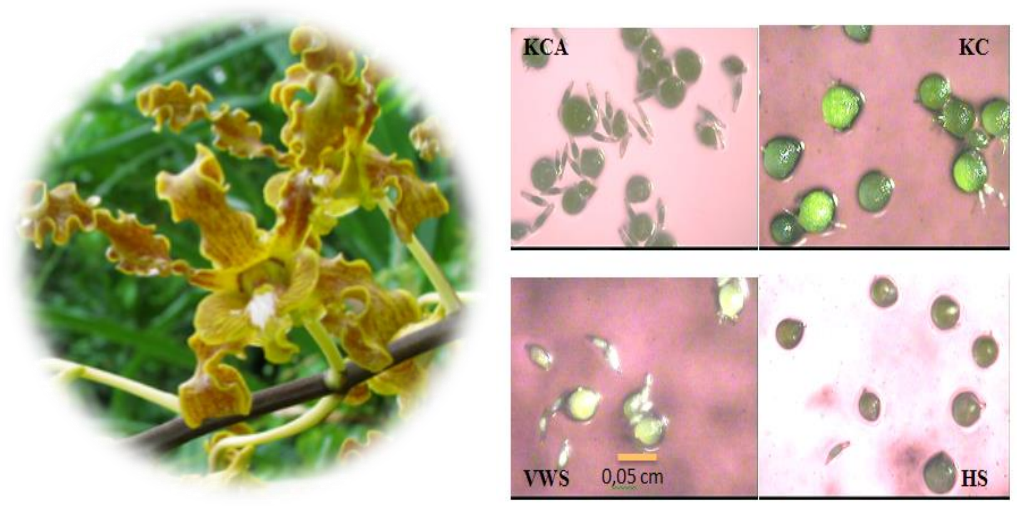

Gambar 5. Morfologi bunga dan pertumbuhan kecambah $D$. discolor pada keempat media semai dari data biji simpanan 9 tahun. Kecambah yang tumbuh pada media HS lebih tinggi persentasenya namun jika dilihat dari perkembangan protokormnya, maka media KC lebih baik untuk mendukung kehidupan protokorm selanjutnya. Foto bunga: https://id.images.search.yahoo.com/yhs/search;
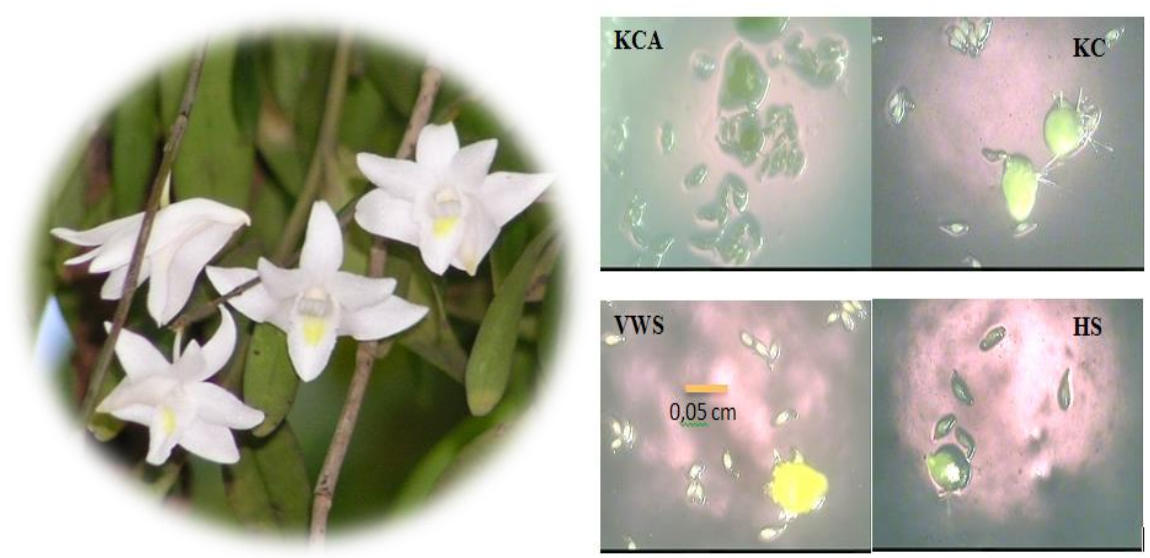

Gambar 6. Morfologi bunga dan pertumbuhan kecambah $D$. crumenatum pada keempat media semai dari data biji simpanan 9 tahun. Dari ketiga media semai yaitu KC, HS, dan VWs tidak ada beda nyata pada hasil persentase kecambahnya, namun yang paling tinggi dan yang menunjukkan perkembangan rhizoid tercepat adalah media KC. Foto bunga: koleksi D.M. Puspitaningtyas

Perkecambahan biji anggrek dipengaruhi oleh berbagai faktor, yaitu eksplan, media, $\mathrm{pH}$, hormon pertumbuhan, dan kondisi kultur (Pradhan et al. 2014). Media semai KC yang merupakan modifikasi dari Knudson'C dengan penambahan bahan organik ekstrak taoge dan air kelapa mampu mendukung perkecambahan terbaik untuk $D$. macrophyllum dan $D$. crumenatum. Efek air kelapa yang mengandung zeatin dan zeatin ribosida sebagai sitokinin utama mendukung pembelahan sel. Selain itu, air kelapa juga mengandung asam amino, asam organik, asam nukleat, beberapa vitamin, gula, dan gula alkohol yang sepenuhnya meningkatkan kualitas pertumbuhan biji menjadi tanaman (Shekarriz et al. 2017). Ekstrak taoge pada media KC mengandung 
karbohidrat, protein, Ca, P, Fe, dan vitamin A, B1, dan C dalam bentuk senyawa larut sehingga memudahkan tanaman untuk menyerap. Pemberian ektrak taoge ini menjadikan tanaman tumbuh lebih baik (Jufri et al. 2014).

Biji D. discolor mampu berkecambah paling baik pada media semai HS yang mengandung bahan organik pepton dan ektrak kentang. Namun demikian media KC juga cukup baik untuk mendukung perkecambahan bijinya. Hal ini sesuai dengan hasil penelitian Tawaro et al. (2008) yang menyebutkan bahwa persentase perkecambahan dan jumlah pembentukan PLB Phalaenopsis meningkat dengan adanya penambahan air kelapa dan pepton pada media semai. Kandungan air kelapa pada media semai sebanyak 10-30\% mampu merangsang pertumbuhan protokorm Cymbidium. Menurut Shekarriz et al. (2017), pepton merupakan enzim atau asam hidrolisat dari jaringan tanaman ataupun hewan yang digunakan sebagai campuran pada media semai Phalaenopsis hibrid 'Manchester', dan terbukti efektif dalam meningkatkan produksi PLB (protocorm like bodies).

Kecambah yang tumbuh pada media KCA terlihat lebih kecil dibandingkan dengan media semai lainnya. Media semai KCA tidak mengandung bahan organik, sehingga nutrisinya lebih sedikit. Namun demikian media KCA cocok untuk perkecambahan anggrek Paphiopedilum supardii (Handini et al. 2016). Dengan demikian, tiap jenis anggrek memiliki kecocokan tersendiri terhadap media semai biji.

Pengujian viabilitas biji yang dilakukan setiap tahun untuk ketiga jenis Dendrobium ini memperlihatkan bahwa persentase kecambah masih tinggi, setelah uji viabilitas di tahun pertama dilakukan. Lain halnya dengan hasil penelitian sebelumnya pada Dendrobium stratiotes yang mempunyai masa hidup biji lebih singkat yaitu hanya sekitar tiga bulan. Persentase kecambah biji menurun drastis dan pada umur sembilan bulan masa simpan biji sudah tidak berkecambah lagi (Puspitaningtyas \& Handini 2011), dibandingkan dengan D. macrophyllum, D. discolor, dan $D$. crumenatum yang memiliki masa simpan hingga 9 tahun bahkan bisa lebih.

Biji anggrek lainnya yang pernah diteliti adalah Paphiopedilum supardii yang kehilangan viabilitasnya pada masa simpan 12 bulan (Handini et al. 2016). Beberapa jenis Coelogyne yang pernah diuji viabilitasnya adalah $C$. rochussenii dan $C$. celebensis yang memiliki periode simpan yang pendek (kurang dari 1 tahun), namun biji $C$. pandurata, $C$. asperata, dan $C$. rumphii masih dapat disimpan selama 1-2 tahun, sedangkan biji yang dapat disimpan selama 3 tahun adalah $C$. foerstermannii dan C. pulverula (Puspitaningtyas \& Handini 2014). Menurut Seaton et al. (2013), penyimpanan biji anggrek seperti $D$. macrophyllum, pada masa penyimpanan 12 bulan masih mempunyai viabilitas biji sekitar $76 \%$ pada masa penyimpanan 12 bulan, sedangkan viabilitas biji D. discolor masih $90 \%$ pada penyimpanan 12 bulan.

Beberapa jenis anggrek mungkin masih mampu tumbuh jika disimpan dalam jangka waktu lama (lebih dari 18 tahun) apabila penyimpanan dilakukan dalam keadaan kering dalam desikator dan pada suhu $0^{\circ} \mathrm{C}$ dalam lemari es (Kano 1965). Selama biji dikeringkan dengan benar, biji berkualitas baik kemungkinan tetap layak disimpan selama beberapa puluh tahun pada suhu $-20^{\circ} \mathrm{C}$ (Seaton \& Pritchard 2003).

Masa hidup biji anggrek dalam penyimpanan dipengaruhi oleh kesesuaian suhu dan kelembapan. Menurut Seaton et al. (2013), kesesuaian cara penyimpanan biji dengan pengaturan suhu dan kadar air dalam biji akan mempengaruhi durasi keberhasilan biji dapat penyimoanan. Fluktuasi persentase kecambah dapat terjadi pada hasil uji kecambah dari tahun ke tahun. $\mathrm{Hal}$ ini dapat disebabkan oleh serangkaian kondisi penyimpanan, seperti suhu, kelembapan, dan kadar air biji saat pengujian. Biji dari beberapa buah yang tercampur dalam satu wadah dapat menjadi penyebab fluktuasi persentase kecambah. Menurut Row \& Wynia (2006), kurangnya keseragaman kualitas biji untuk disimpan, variasi dalam lingkungan germinator, dan tidak konsisten dalam penanganan biji dan pengambilan data juga dapat menciptakan peluang terjadinya variasi di laboratorium.

\section{KESIMPULAN}

Berdasarkan perkiraan, masa hidup $D$. discolor dapat disimpan lebih lama dibandingkan dengan $D$. macrophyllum dan $D$. crumenatum. Biji $D$. discolor memiliki persentase kecambah lebih tinggi dibandingkan D. macrophyllum dan $D$. crumenatum pada masa simpan biji sembilan tahun. Media KC adalah media yang menghasilkan persentase kecambah tertinggi untuk biji $D$. macrophyllum dan $D$. crumenatum, sedangkan biji $D$. discolor berkecambah baik pada media HS. Secara umum media KC dapat dipakai sebagai media semai yang baik untuk mendukung pertumbuhan dan perkembangan kecambah ketiga jenis biji anggrek tersebut.

\section{UCAPAN TERIMA KASIH}

Ucapan terima kasih disampaikan kepada Hugh W. Pritchard dan Philip Seaton sebagai manajer proyek Orchid Seed Stores for Sustainable Use (OSSSU) yang telah mendanai kegiatan penelitian ini. Ucapan terima kasih 
juga disampaikan kepada Pusat Penelitian Konservasi Tumbuhan dan Kebun Raya-LIPI atas fasilitas penelitian yang diberikan dan pengawas Laboratorium Kultur Jaringan Kebun Raya Bogor.

\section{DAFTAR PUSTAKA}

Anonim. 1997. The State of the World's Plant Genetic Resources for Food and Agriculture. Food and Agriculture Organization of the United Nations, Rome.

Darmawati IAP, Rai IN, Dwiyani R, Astarini IA. 2018. The diversity of wild Dendrobium (Orchidaceae) in Central Bali, Indonesia. Biodiversitas 19(3): 1110-1116.

Gupta A. 2016. A symbiotic seed germination in orchids: Role of organic additives. International Advanced Research Journal in Science, Engineering and Technology 3(5): 143-147.

Handini E, Puspitaningtyas DM, Garvita RV. 2016. Konservasi Paphiopedilum supardii Braem \& Loeb dengan metode penyimpanan biji dan perbanyakan secara in vitro. Buletin Kebun Raya 19(2): 117-127.

Hosomi ST, Santos RT, Custodio CC, Seaton PT, Marks TR, Machado-Neto NB. 2011. Preconditioning Cattleya seeds to improve the efficacy of the tetrazolium test for viability. Seed Science and Technology 39: 178-189.

Hossain M, Dey R. 2013. Multiple regeneration pathways in Spathoglottis plicata Blume - A study in vitro. South African Journal of Botany 85: 56-62.

Jufri N, Abdullah D, Susanti D. 2014. The use of bean sprouts extract as supplement for the growth of plaintain unti sayang (Musa paradisiaca L.) by tissue culture. Journal of Agriculture Studies 2(1): 99-106.

Kano K. 1965. Studies on media for orchid seed germination. Memoirs of the Faculty of Agriculture, Kagawa University, No. 20.

Linington SH, Pritchard WH. 2001. Gene banks. in: Levin SA (ed.). Encyclopedia of biodiversity, 3: 165-181. Academic Press, New York

Merritt DJ, Hay FR, Swarts ND, Sommerville KD, Dixon KW. 2014. Ex situ conservation and cryopreservation of orchid germplasm. International Journal of Plant Sciences 175(1): 46-58.

Nadarajan J, Wood S, Marks TR, Seaton PT, Pritchard HW. 2011. Nutritional requirements for in vitro seed germination of 12 terrestrial, lithophytic, and epiphytic orchids. Journal of Tropical Forest Science 23(2): 204-212.

Pradhan S, Tiruwa B, Subedee BR, Pant B. 2014 In vitro germination and propagation of a threatened medicinal orchid, Cymbidium aloifolium (L.) Sw. through artificial seed. Asian Pacific Journal of Tropical Biomedicine 4(12): 971-976.

Pritchard HW. 1985. Determination of orchid seed viability using fluorescein diacetate (Technical Report). Plant Cell and Environment 8: 727-730.

Puspitaningtyas DM, Handini E. 2011. Uji daya simpan biji anggrek Dendrobium stratiotes Rchb.f. Prosiding Seminar
Nasional Konservasi Terkini dan Tantangan ke Depan. Cibodas, 7 April 2011. UPT BKT Kebun Raya Cibodas LIPI, Cianjur.

Puspitaningtyas DM, Handini E. 2014. Penyimpanan biji anggrek Coelogyne spp. untuk konservasi ex situ. Buletin Kebun Raya 17(2): 101-112.

Rahayu EMD, Mulyani M. 2020. Perkecambahan asimbiotik biji dan perkembangan planlet Dendrobium spectabile (Blume) Miq. Buletin Kebun Raya 23(1):25-35.

Row JM, Wynia RL. 2006. Viability of native ford seeds stored under two different environments. Prairie invanders: Proceeding of the 20th North American Prairie Conference. University of Nebraska at Kearney. edited by Springer JT, Springer EC. Kearney, Nebraska: University of Nebraska at Kearney, 177-186 pp.

Sandrasagaran UM, Subramaniam S, Murugaiyah V. 2014. New perspective of Dendrobium crumenatum orchid for antimicrobial activity against selected pathogenic bacteria. Pakistan Journal of Botany 46 (2): 719-724.

Seaton P, Hu H, Perner H. 2010. Ex situ conservation of orchids in a warming world. Botanical Review 2010: 1-11.

Seaton P, Kendon JP, Pritchard HW, Puspitaningtyas DM, Marks TR. 2013. Orchid conservation: The next ten years. Lankersteriana 13(1-2): 93-101.

Seaton P, Ramsay M. 2005. Growing orchids from seed. Royal Botanic Gardens, Kew.

Seaton P, Pritchard HW. 2003. Orchid germplasm collection, storage and exchange. In Dixon, KW, Kell SP, Barrett RL, Cribb PJ. (eds.). Orchid conservation. Natural History Publications, Kota Kinabalu, Sabah. 227-258 pp.

Seaton P, Pritchard HW. 2011. Orchid seed stores for sustainable use: A model for future seed-banking activities. Lankesteriana 11(3): 349-353.

Semiarti E. 2012. Kebutuhan inovasi dalam pengembangan industri anggrek yang berdaya saing dan berbasis sumber daya lokal. Prosiding Seminar Nasional Anggrek. Pengembangan inovasi teknologi mendukung pengembangan industri anggrek yang berdaya saing berbasis sumber daya lokal. Pusat Penelitian dan Pengembangan Hortikultura. hal 21-27.

Shekarriz P, Kafi M, Deilamy SD, Mirmasoumi M. 2017. Coconut water and peptone improve seed germination and protocorm like body formation of hybrid Phalaenopsis. Agriculture Science Development 3(10): 317-322.

Singh F. 1981. Differential staining of orchid seeds for viability testing. American Orchid Society Bulletin 50(4): 418419.

Tawaro S, Suraninpong P, Chanprame S. 2008. Germination and regeneration of Cymbidium finlaysonianum Lindl. on a medium supplemented with some organic sources. Walailak Journal of Science and Technology 5(2): 125135.

van Waes JM, Debergh PC. 1986. Adaption of the tetrazolium method for testing the seed viability, and scanning electron microscopy study of some western European orchids. Physiologia Plantarum 66: 435-442. 
Whigham DF, O'Neill JP, Rasmunssen H.N, Caldwell BA, McCormick MK. 2006. Seed longevity in terrestrial orchids - Potential for persistent in situ seed banks. Biological Conservation 129: 24-30.
Widiastoety D, Solvia N, Soedarjo M. 2010. Potensi anggrek Dendrobium dalam meningkatkan variasi dan kualitas anggrek bunga potong. Jurnal Litbang Pertanian 29(3): 101-106. 